\title{
Arabic Names for Young Children: Evaluating Muslim Javanese Identity
}

\author{
Ajar Pradika \\ English Letters Department \\ Universitas Ahmad Dahlan Yogyakarta, Indonesia \\ Syarif Hidayatullah State Islamic University \\ Jakarta, Indonesia \\ ajar.pradikadenlitera.uad.ac.id
}

\begin{abstract}
The essence of names in a multilingualmulticultural nation is as an identity. These names will give a special identity to a person in the development of his/her personality. Selecting names is not merely a ritual dedicated to just-born babies but it is also a hope and a prayer with meaningful denotation. Since Indonesia is called as Muslimmajority nation, the people consider their Islamic traditions completed by some guidelines taught in religious teaching to choose the best names for their children. However, a missing link appears from generation to generation. They consider the form of Arabic names more than local names in order to reflect the Muslim identity. In addition, the uniqueness, complexity of words, and harmony in sound are the other considerations to choose names for their children in this globalization era. The mindset has changed that prestige has more attention than the values in naming practice. The focus of this research is on selecting Indonesian young children names with special reference to identity and socio-cultural changes in the society facing the globalization era. Factors affecting the above such as language, culture, technology, and public figure aspirations can be a considerate attention in evaluating the perception of their mindset in selecting names for their children because this seemingly rises to problems of identity. Besides, the reasons why naming associates with Indonesians' identity identification is investigated in this research. This research is conducted in Daerah Istimewa Yogyakarta (Yogyakarta Special District) which people regard as a miniature of Indonesia where Javanese ethnic groups as the majority live in harmony with other ethnics, even with foreigners. The atmosphere in Yogyakarta is quite dynamic enabling the interspersing of many cultures from the entire of the world.
\end{abstract}

Keywords-- identity; naming; globalization; Islam; Javanese

\section{I.INTRODUCTION}

Wong Jawa Ilang Jawane", Javanese lose their own identity, is a satire expression criticizing Javanese today. This satire arises as the effect of a narrow interpretation of globalization among Indonesians, contextually Javanese, which threatens the existence of Javanese identity. To Javanese, being globalized residents connotes being westernized ones including adopting all its traditions and putting westernized things in the first position. They are as if in competition to have everything westernized because it gives them more pride in front of the society. Yet, toward Javanese people who still maintain the local wisdom and traditions including when naming their children, people will considered them as obsolete. Many people now tend to

\author{
Ananta Tur \\ English Letters Department \\ Universitas Ahmad Dahlan Yogyakarta, \\ Syarif Hidayatullah State Islamic University Jakarta \\ Indonesia \\ ajar.ananta@gmail.com
}

choose westernized vocabularies, articulations, and choice of words.

Name and identity are two inseparable things. For Muslim, selecting names is not merely a ritual dedicated to just-born babies but it is also a declaration of hopes and prayers with meaningful denotation. Name can also give instant information about social background, culture, language, and even religion as well as identity. In any event, name will be something about which people are concerned, something with which they show their identity, or identities of others they want to emphasize. The naming of Chinese origin living in Indonesia is the best example to explain it. They prefer to choose names "that sound Javanese". They want to emphasize and show their second identity in order to be accepted as individuals by the indigenous people Bailey and Lie, [1]. In contrast, Muslim Javanese slowly leave their naming tradition and identity since this millennium.

Special District of Yogyakarta (DIY), called shortly as Yogyakarta, was the Kingdom of Javanese, Mataram Kingdom, but now is a Yogyakarta Sultanate after joining the Republic of Indonesia. It has been led by truly Javanese descendants of Sri Sultan Hamengkubuwono, called Sri Sultan. When the $10^{\text {th }}$ descendant of Sri Sultan, BRM Herjuno Darpito, was mandated to be the next king of Yogyakarta Sultanate at March 7, 1989, he chose a noble title "Ngarsa Dalem Sampeyan Dalem ingkang Sinuwun Kangjeng Sultan Hamengku Buwana Senapati-ing- Ngalaga Ngabdurrakhman Sayidin Panatagama Kalifatullah ingkang Jumeneng Kaping Sadasa ing Ngayogyakarta Hadiningrat”. However, on April 30 $0^{\text {th }}$, 2015 through Sabda Raja he changed his title by revising some Javanese words and deleting two non-Javanese words which were Khalifatullah and Sayidin. Both were Arabic which were formerly considered as the symbol of Islamic Kingdom in Java. Now, his noble title is "Ngarso Dalem Sampeyan Dalem Ingkang Sinuwun Sri Sultan Hamengku Bawono Ingkang Jumeneng Kasepuluh Suryaning Mataram Senopati Ing Ngalogo Langgeng ing Bawono Langgeng, Langgeng ing Tata Panatagama" Huda, [2]. This decision was initiated by his restlessness of naming system in Yogyakarta Sultanate. Javanese people, the majority ethnicity in Yogyakarta, prefer to have non-Javanese names for their young generations. Of course, it will affect their identity in the near future, not only the identity of the people but also the identity of the sultanate.

In two villages in Gunungkidul Yogyakarta named 
Panggang and Paliyan villages, for example, most of the young children have westernized names, including the name patterns, which are difficult in spelling, both spoken and written. The areas are two of the remote areas in Yogyakarta and it is quite difficult to make a contact with people in the town. The internet connection is not well established too. Yet, they can get a reference to the naming practice in the westernized way. How can they access such reference in naming?

Considering the aforementioned information, this research would like to investigate what factors affecting the Muslim Javanese in Yogyakarta in their naming practice and how they reckon Javanese names compared to westernized names in naming their children in the millennium. Furthermore, to portray the changes in society in the near future, this research would also explain the existence of the identity of Muslim Javanese through naming practice in facing global era.

\section{METHOD}

This research is categorized as a descriptive qualitative research design. It can be justified by the data analyses which are mostly descriptions of names used by young children in Yogyakarta. Although there are some computations using percentages in portraying the use of names, these all are only regarded as minor components in order to support the qualitative analysis.

To collect the data, this research conducted a field observation and a detailed procedure is stated below:

1) Identifying schools/community either states or private ones or public information place related to residency in Yogyakarta,

2) Asking permission to copy the children profile database for the sake of research from the databases,

3) Identifying the children profile database through purposive sampling to conduct a deep recorded interview with their parents,

4) Categorizing the data collected from the database and the interviews to support the analysis,

5) Concluding the result of the analysis in deep and clear conclusion.

\section{RESULT AND DISCUSSION}

In Islamic religious teaching, Muslims are taught to choose the best names for their descendants Hoesterey, [3]. It is since the names can reflect the hope and prayer of their parents, not merely the code to differentiate among people in a public entity. This teaching spread out hand-in-hand with the growth of Islam in almost all countries in the world. Because each country has its own culture, cultural acculturation becomes a win-win solution as a form of obedience toward Islam while still keeping cultural identity. This occurs in Javanese Muslims as well.

\section{A. The Characteristics of Muslim Javanese Names}

Kuipers and Askuri [4] quoted Uhlenbeck idea about Javanese people that they have characteristics in giving names. The two major considerations in doing it are gender and social status. Most Javanese names fall into male (often ending in $-o$ ) and female (often ending in $-i$ ) categories. Both categories have varieties that indicate class: female names that end in -em or -en are often associated with lowclass status while corresponding male names are those ending in - an, -in, and - un. Besides, Javanese also have some varieties of names according to their functions such as child names and mature names, nicknames, and names used to cure someone latent illnesses. Those three kinds of names have their own characteristics.

The word choice in naming is the priority but defining how many names the parents will give to their children is also a big deal. Javanese is closely related to a single name for a child Djatmika, [5]. This condition reflects the social status the parents have. Often, those who have more than one names are considered as noble children or their families are considered as the relatives of Kingdom ancestral. We can see from the name of our Sultan, Sri Sultan HB X as I mentioned in the background.

As time goes by, the main characters of the Javanese identity marker have shifted. The shift is marked by the emergence of the internet that provides easy access for new parents to search for names according to their will. Although the concept of naming does not change, the influence of language and public figures has its own space in the minds of young parents in giving names to their children.

\section{B. Arabic Names and Public Figures Effects}

Arabic names for Javanese people, especially those considered to be qualified in religious teaching in the past, could be like a sacramental name that must be chosen. There was a pride attached by the parents to the child who had the Arabic name. Until today, the Arabic name trends are still thriving. For example, parents prefer the name 'Akbar' rather than 'Agung', the name 'Wahid' is preferred over 'Eko' which have the same meaning.

Because of the massive use of Arabic names in the Javanese society since the past, the name of 'Javanese-like Arab' becomes a common idiom in society Hendrawanto, [6]. The Javanese society does not feel marginalized or colonized by the emergence of the Arabic names which are increasingly popular. Even, in some cases, the Arabic names can be considered as Javanese ones. They blend into one socio-cultural identity. However, the inferior feelings or low self-esteem often appear de Grave, [7]. Those who have Arabic names can be considered as having high social status and vice versa. The consequence of this is the Javanese names are often placed in a cultural waste by means of joke or satire.

A very phenomenal moment in America, known as 9/11 tragedy, on the one hand, gives a deep sadness for Muslims. Muslims are persecuted as terrorists, even until now. It also 
affects the naming tradition among Muslims. Recently, the State's immigration office rejected people with Arabic names from entering the U.S. territory. On the other hand, it is assumed that Javanese names will be more preferable to have. Yet it is not the case. The Javanese names are still the number two after the booming of the use of English or Westernized names.

The situation is fully supported by the presence of technological devices that makes the English or Westernized names become viral. Through the internet, people are competing to find and install the names to children with unique, rhythmic and meaningful names even though they are sometimes difficult to articulate. 'Nixon Carlotta' is the example of the names. It is owned by a student of one Muhammadiyah Elementary School in Yogyakarta.

Arab and English or Westernized names are not necessarily without any reference. The love of someone who is affirmed by society helps the name searching process. For example, in Bantul, parents named his son 'Muhammad Arifin Ilham' because they idolize Arifin Ilham as a person who possesses the deep knowledge of religion, hoping that their son could follow in his steps and choice of life. There is also 'Yusuf Zainuddin Nasir' who follows the pattern of naming. However, the name 'Nasir' is the child's parent's name. This pattern, of attaching a family name/ surname, does not exist in the Javanese culture but English or Westernized one.

In the past, following the names of Western people could be considered by the community as a gentile or Christian. They had in their minds that Arab names represent Islam and all of the Western people were nonMuslim. However, that paradigm today has becomes an unjustified stereotype. Even nowadays, western names are the trend to accompany the Arab names among Javanese. The most commonly referred names of western are the names of known football players such as Zidane, Zlatan, Robin, Frank Ribery, Ozil, Khedira, and others. We may see the name of a kid in Bantul 'Zlatan Arkana Wiryawan'. We may also consider these names of students in one of State Elementary Schools in Yogyakarta 'Ananda Khedira Putri', 'Muhammad Tristan Setyawan', and 'Damario Bintang Zidane Ramadhan'.

\section{Mixing the Names}

The existence of various types of names in the Javanese society clearly has to a certain degree some impacts on the Javanese identity. Furthermore, the sense of having an identity can be disrupted if this practice is not evaluated immediately. It has been acknowledged by linguists that name is an important part of an individual's identity representing a shift in the value of the society. To make it simple, in this globalization era, people, who do not know each other, from all over the world may mingle in one place. They have the same names pattern or even vocabularies. It will be difficult for us to identify each of them, and thus it affects how we treat them personally. Every place has its own culture, even in communication. You cannot say 'hi' or "hello" with the same attitude to all people you meet.

A name is no longer seen as an identity attached to the individual since it is given but the name now becomes an ornament displayed in the public space. The essence of the display is aesthetic. However, aesthetic can be interpreted by thousand heads which experience different backgrounds influencing different interpretations. Religious teaching is actually still the foundation of giving names. However, after the foundation is fulfilled, the rest of the naming process is an 'art performance' concatenating words to reinforce the foundation with unique vocabularies, extravagant spelling, or rhythm of the name that sounds pleasant to the ear Rusman dan Mariani, [8].

The phenomenon that emerges today as a form of identity preservation is mixing the names. This social deal is born and developed without any instruction from the government or other parties. This is truly the awareness of society about identity. However, the awareness seems only partial because the mergers of the names are only involving the Arab names, the Westernized names of the public figures, and the last names of the parents that are not merely taken from the characteristics of Javanese names.

\section{CONCLUSION}

Naming is an important part of giving identity. Besides reflecting the culture, naming also implies hopes and prayers of parents toward their children. Parents always look for and choose the best ones. This value is not bordered by language use because every place has its culture and the wealth of languages. Those two things are the notification of identity. They can go down to how parents choose the best names for their children by identifying the use of languages.

Recently, the internet offers easiness to access much information about anything, including naming. On the one hand, it will be helpful for people who look for the best names for their children closely related to their hopes and prayers towards the children. On the other hand, the sense of belonging towards own culture slowly disappeared, as what happens to Javanese people. They actually have their characters in naming but they prefer to choose other languages such as Arab or Westernized names. Unfortunately, in this decade, children are shy to have Javanese names because the names are often exploited as a means of bullying orjokes.

This condition must be evaluated by looking at the choice of names influenced by culture, public figures, and how the parents create names. Although, the utopia of the past still exists today, in the millennial era, and about the ancestral matters reflect their social status, it does not matter a lot because technology offers more interests to the young generation. Besides, the public figure affects significantly towards young parents to pick their favorite public figure's names partially for their children as a means of pride. Consequently, Javanese names come into number three as the source of names. Even, the names usually are used to complete the other Arab and Westernized names. People say 
it is a matter of maintaining Javanese identity by mixing names. Yet, this practice must be carefully appraised.

\section{REFERENCES}

[1] B. Bailey and Sunny Lie, "The Politics of Names Among Chinese Indonesians in Java.)," J. Linguist. Anthropol., vol. 23, no. 1, pp. 21-40, 2013.

[2] M. N. Huda, "Ini Gelar Sultan HB X Sesuai Sabdaraja dan Penjelasannya," Tribun Jogja, Jogja, Mei 23:03-2015.

[3] J. Hoesterey, Rebranding Islam: Piety, Prosperity, and a Self-Help Guru. Stanford: Stanford University Press, 2015.

[4] J. C. Kuipers and Askuri, "Islamization and Identity in Indonesia: The Case of Arabic Names in Java," Indonesia, vol. 103, 2017.

[5] Djatmika, "Pemberian Nama Panggilian Dalam Masyarakat Jawa".," 2011.

[6] R. Hendrawanto, “Antara Islam Dan Budaya Arab," Kompasiana, Desember 2014.

[7] de Grave and Jean-Marc, "Naming as a Dynamic Process," Indones. Malay World, vol. 39, no. 113, pp. 69-88, 2011.

[8] Rusman and Evi Mariani, "Long Difficult Names for Kids is the New Trend in Indonesia," Jkt. Post, Sep. 2014. 